\title{
The Role of Cognitive Style in the Collocational Knowledge Development of Iranian EFL Learners through Input Flood Treatment
}

\author{
Elaheh Hamed Mahvelati ${ }^{1} \&$ Jayakaran Mukundan ${ }^{1}$ \\ ${ }^{1}$ Department of Language and Humanities Education, Faculty of Educational Studies, Universiti Putra Malaysia, \\ Malaysia \\ Correspondence: Jayakaran Mukundan, Department of Language and Humanities Education, Faculty of \\ Educational Studies, Universiti Putra Malaysia, 43400 UPM Serdang, Selangor, Malaysia. Tel: 12-209-9717. Fax: \\ 603-8943-5386. E-mail: jayakaranmukundan@yahoo.com
}

Received: July 11, 2012 Accepted: August 3, 2012 Online Published: August 23, 2012

doi:10.5539/elt.v5n10p105 URL: http://dx.doi.org/10.5539/elt.v5n10p105

\begin{abstract}
The differences in cognitive style between individuals and the effect these differences can have on second language learning have long been recognized by educators and researchers. Hence, this issue is the focal center of the present study. More precisely, the purpose of this study was to investigate the role of participants' cognitive style (field-dependence vs. field independence) in their collocational knowledge development. That is, the study explored possible differences between field-dependent and field-independent learners with regard to the role of input flood treatment as an implicit method of collocation instruction.

Two intact classes comprising sixty-four upper-intermediate learners with roughly the same level of language proficiency participated in this study. One class was randomly assigned to the experimental group and the other to the control group. The analysis of the data revealed that input flood treatment improved the performance of the experimental group at post-test stage. A deeper analysis concerning the differences between field-dependent/ independent learners, however, indicated that this kind of teaching approach was more beneficial for field-independent learners in both short and long term. Moreover, the results of within-field-dependent/ independent group showed that while input flood treatment did not have long-term effect on improving the field-dependent's knowledge of the target collocations, it had durable effect on the field-independent's collocation development.
\end{abstract}

Keywords: input flood treatment, knowledge of collocation, cognitive style of field-dependence and field-independence

\section{Introduction}

Collocation has proved to be an important constituent of language learners' linguistic competence, and therefore many researchers have emphasized the importance of it in theories of second language acquisition in recent years (Alsakran, 2011; Bahns \& Eldaw, 1993; Coady \& Huckin, 1997; Durrant \& Schmitt, 2010; Goudarzi \& Moini, 2012; Lewis, 2000; Nesselhauf, 2003; Shokouhi \& Mirsalari, 2010; Sinclair, 1991; Zahedi \& Mirzade, 2010). Nevertheless, pedagogical materials for the learners of English as a Foreign (EFL) or second Language (ESL) have only recently begun to promote the treatment of collocations (Hsu, 2007).

A review of literature shows that only few studies have been conducted to examine the viable ways to facilitate collocation learning in the language classroom, and much of the related work only discusses the theories of collocational competence and collocational problematic areas in the English language (Allerton, 1984; Howarth, 1998) or investigation of the need for collocation learning (Bahns, 1993; Bahns \& Eldaw, 1993; Lennon, 1996) and EFL/ESL learners' use of collocations (Zughoul, 1991; Farfhal \& Obiedat, 1995). Thus, pedagogical exploration of practical ways to promote EFL learners' collocation learning is needed since it has been proved in many studies that collocation is a big challenge for second language (L2) learners.

One of the viable ways that is believed to be beneficial for language learners to develop their knowledge of collocation is input flood treatment. Input flood as an implicit method of teaching collocation have been proved effective by some researchers such as Öztina (2009) and Zaferanieh \& Behrooznia (2011). However, there is a huge gap in their studies which is aimed to be filled by the present study. That is, these researchers ignored the 
prominent role of the learners' individual differences in their cognitive style and the degree to which these differences may affect their learning results.

Cognitive style of field dependence-independence is one of these learner characteristics which is widely studied and its widespread application in SLA has been proved in a number of studies (Arp, Woodard \& Mestre, 2008; Dawson-Brew, 2010; Gul, 2009; Nodoushan, 2006; Sims \& Sims, 2006; Witkin \& Goodenough, 1981). It refers to how globally or analytically one approaches a task or processes information (Hadley, 2003). Thus, when the efficiency of a particular instruction is concerned, the type of the learners who receive the treatment is of great importance. More specifically, in the case of input flood treatment as an implicit method of teaching, which is the concern of this study, the learners are amply exposed to the texts and sentences that include the target items but their attention is not directly drawn to the target features and they are only asked to read the texts for comprehension purposes. As a result, the manner in which field-dependent/independent learners approach the task can affect their learning success. In other words, the strategies that they bring to this learning environment can facilitate or hamper their process of learning.

\subsection{Research Questions}

1. Does the input flood treatment have any effects on the learners' knowledge of collocation?

2. Are there any significant differences between the field-dependent and field-independent learners' knowledge of collocation as a result of the input flood treatment?

\section{Literature Review}

\subsection{Collocation}

The term "collocation' has its roots in "the Latin verb 'collocare' which means 'to set in order/to arrange"', and Firth (1957) defines it as "a combination of words associated with each other" (quoted in Martyńska, 2004, p. 2). According to the structural approach, it is not possible to separate grammar from lexis since they complete each other (Fan, 2009; Shehata, 2008). Thus, within this approach, two major types of collocation are defined: lexical and grammatical collocation (Benson, Benson \& Ilson, 1997; Lewis, 2001; Wei, 1999).

Grammatical collocations contain the combinations of a noun, a verb or an adjective and a preposition or a grammatical structure (Hill, 2000; Lewis, 2000; Wu et al., 2010). In contrast, lexical collocations do not consist of grammatical elements, but are combinations of nouns, adjectives, verbs and adverbs (Bahns, 1993; Le, 2010).

In addition to the above categorization, as Pei (2008) points out, collocation knowledge also falls into two categories: receptive and productive knowledge. While fill-in-the-blank/cloze and translation tasks are generally used to investigate learners' productive knowledge, multiple choice questions are used for testing learners' receptive knowledge.

\subsection{Input Flood Treatment}

It is worth noting that the need for calling educators' and syllabus designers' attention to integrate collocations into the language syllabus in an effective and principled way is not only suggested by Bahns \& Eldaw (1993), but has also been stressed by many applied and educational linguists (Fan, 2009; Hill, 2000; Lewis, 2000; lin, 2002; Motallebzadeh et al., 2011).

The proponents of implicit instruction believe that lexical items can be learned implicitly "from context alone" (Krashen, 1989, p. 440). However, some of them point out that mere exposure, which is suggested by Krashen's Input Theory (1981), is not sufficient for language learners to notice and acquire the targeted features in input. In other words, as Schmidt (1990) notes in his Noticing Hypothesis, input has no practical value and cannot become available for intake and effective processing if it is not noticed by the learners. Hence, some input enhancement techniques are needed to enhance the chance of noticing and acquiring of those target linguistic items (Gass, 1997; Hernandez, 2008; Schmidt, 1990; Sharwood-Smith, 1993; Wong, 2005).

Input flood treatment, which is the concern of the present study and is regarded as an implicit method of teaching collocation, is one of the input enhancement techniques (White, 2008). Input flood treatment includes the artificially increased incidence of the target items in the audio and visual texts that learners are exposed to without any explicit instruction or feedback (Öztina, 2009). Thus, learning the target items in such a treatment is a by-product of the reading/listening comprehension activity. Moreover, as Gass (1997)and Wong (2005) point out, the basic idea in this kind of treatment is that flooding the input with the target items increases the chance of noticing those items since it is highly likely that learners attend to something that occurs frequently in the input. The effectiveness of this treatment has been examined by some researchers (Laufer, 2006; Öztina, 2009; Rassaei \& Karbor, 2012; Seiba, 2001; Trahey \& white, 1993; White, 2008; Williams \& Evans, 1998), but their mixed 
findings indicate that there is still a need for more research on this issue.

Contrary to the implicit instruction proponents' claim, some researchers, such as Grabe \& Stoller (1997) Schmitt \& McCarthy (2002) and Waring \& Takaki (2003) who conducted studies on the impact of implicit instruction on vocabulary and collocation learning found that the implicit methods of instruction are time-consuming and their effectiveness is not that much significant to have durable effect.

As it was mentioned before, when the aim of a study is to explore the effectiveness of a teaching method, the learners' cognitive style, as an effective factor, should be taken into account.

\subsection{Field Dependence-independence and Second Language Learning}

There seems to be two contradictory views on the role of field-dependence/independence in L2 learning. Besides a considerable number of researchers who have conducted various studies to prove the significant relationship between field-dependence/independence and L2 learning, there are a few researchers, such as Ellis (1994) and Griffith \& Sheen (1992), who assert that field dependence-independence has no role in L2 learning and believe that this concept is "theoretically flawed" (Griffith \& Sheen, 1992, p. 133). This view was also supported by the findings of Dryer \& Osborne's (1999) study on secondary agricultural education students which suggested that the learners' cognitive style of field-dependence/independence did not affect the effectiveness of different teaching approaches.

The main characteristics of the field-dependent and field-independent cognitive styles, in this study, are defined according to the definition given by Witkin \& Goodenough (1981) as (quoted in Danili \& Reid, 2006, p. 67):

Field - Dependent (FD) individual: one who can insufficiently separate an item from its context and who readily accepts the dominating field or context.

Field - Independent (FID) individual: one who can easily ‘break up' an organised perceptual field and separate readily an item from its context.

Hence, as Tianjero et al. (2011) puts it, the most suitable teaching methods for field-dependent learners are those which are directive and supportive since they need external support and guidance to direct their attention towards the details, help them to work out the rules and store information in their working memory in an organized way to be able to retrieve them effectively from their long term memory.

In contrast, field-independent learners, who are more intrinsically motivated to develop their own strategies, seem to need minimum direction and prefer discovery methods which allow them to be more autonomous (Tiajerro, 2011; Witkin et al., 1977). Furthermore, In addition to their superiority in the learning tasks that require analysis and attention to details, they can retrieve information from their working memory much more effectively since they are more disciplined in processing and storing the information (Daniels, 1996).

In sum, this body of research raises this question as to whether implicit method of teaching collocation can cause differences in students' performance due to their cognitive style of field-dependence/independence. If so, instruction should be tailored to suit the needs of particular students.

Although some studies have examined the effect of learners' cognitive style of field-dependence/independence on some aspects of L2 learning, e.g., grammar by Abraham (1985), it is difficult to find a study that directly investigates its effect on collocation learning. Thus, this study attempts to fill this gap and find answers for the above question.

\section{Methodology}

\subsection{Participants}

The participants of this study were sixty-four Iranian upper-intermediate adults studying English in a language centre in Mashhad, Iran. They were randomly assigned to the two groups of control and experimental.

It is worth noting here that only those students served as the subjects in this study that participated in all the tests and were not absent from class for more than three sessions and those who fell in the category of field-intermediate in the GEFT test were excluded.

\subsection{Instruments}

\subsubsection{The Proficiency Test}

In order to determine the proficiency level of the subjects, a TOEFL Paper-Based Test (PBT) was administered. The aim was to select homogeneous groups at the very beginning of the experiment.

\subsubsection{The Group Embedded Figures Test (GEFT)}

To identify the subjects' cognitive style of field-dependence or field-independence, the GEFT, which was 
developed by Oltman, Raskin \& Witkin (1971), was administered. They reported that the reliability of the instrument was .89 and its validity was .82 (Foel \& Fritz, 1994). Among all the various instruments that have been introduced for assessing the cognitive style of field-dependence/independence, this test has been the most common instrument applied by researchers(Alavi \& Kaivanpanah, 2009; Chen \& Macredie, 2001; Fyle, 2009; Hall, 2000; Yousefi, 2011). As Altun \& Cakan (2006) put it, GEFT is the most appropriate instrument since only a minimum level of language proficiency is required for performing its tasks, and different studies on its psychometrical properties in cross-cultural settings have demonstrated that it is a reasonable test to be used in different settings.

Hence, this paper-and-pencil test, which consists of three sections, was used in this study. In each section, the subjects were required to recognize the simple forms that were hidden in complex geometric figures. The first section, which was designed for practice, contained seven figures and the second and third sections each included nine complex figures. Each correctly identified simple forms in the second and third sections of the test deserved one score. Thus, the total possible score for each participant was 18. To determine the subjects' cognitive style, the criterion used by Scardamalia (1977), Case (1974) and Case and Golberson (1974) was used. According to this criterion, students who had a score less than $1 / 4 \mathrm{SD}$ below the mean were classified as field-dependent and the students who had a score more than $1 / 4$ SD above the mean for the sample population were considered field-independent. Those students who scored between mean $-1 / 4$ SD and mean $+1 / 4$ SD was considered field-intermediate learners. The reliability of the GEFT in the present study was calculated as .79 .

\subsubsection{Background Questionnaire}

A background questionnaire was given to the subjects to obtain background information on their language learning experiences and more specifically the treatments that they had received for learning vocabulary. In other words, it was given in order to become sure that only those who had not been introduced to the concept of collocation before and had not experienced the same treatment as the one they would receive in this study would serve as the participants of the present study.

\subsubsection{Teaching Materials}

In addition to the course book, which was a general proficiency course book offering practice in the four skills, some reading texts and materials that contained the target lexical and grammatical collocations were also used for the input flood treatment. These materials that were followed by different exercises were aimed to expose the subjects in the experimental group to the target collocations many times.

\subsubsection{The Target Collocations}

The words that the learners were expected to learn their collocationl fields were not new but they were already half-known words that the learners have difficulty with the correct usage of them. In other words, the subjects had sufficient knowledge about their semantic features, but when it came to using them, they encountered serious problems. For example, the words were as easy as "smoker", "family", "disappointed", etc. that even pre-intermediate learners know their meanings, but when it comes to exploring their collocational fields, even the advanced learners are challenged (Hill, 1999).

\subsubsection{Tests of Collocations}

Three tests of collocation as pre, immediate and delayed post-test were used to investigate the effect of input flood treatment on the learners' knowledge of collocation. Each test consisted of two parts which assessed the learners' both receptive and productive knowledge of collocation. The first part which was designed to measure the subjects' productive knowledge of collocation was in the form of gap-filling test. When the subjects finished the first part of the test, and all the answer sheets were collected by the teacher, the second part, which was used to evaluate the participants' receptive knowledge of collocation through multiple-choice items, was given to the subjects. Hence, the subjects were awarded two scores for each test and the average of these scores was the final score of each student on pre-test and post-tests. It is important to note that these tests were based on what was covered in the experimental class during the treatment period. All the three pre, immediate and delayed post-tests measured the same 50 target collocations, but they were used in different contexts and were reordered each time. These tests, which were made up of both lexical and grammatical collocations, consisted of the following types of collocations:
1. Noun+noun
2. Noun+verb
3. Verb+noun 


\section{Adjective+noun}

5. Adverb+adjective

6. Verb+adverb

7. Noun+ preposition

8. Preposition+noun

9. Adjective+preposition

10. Linking verb collocations (become/get/turn/go collocations)

In order to estimate the reliability of the receptive parts of the tests, they were piloted and the Cronbach's $\alpha$ formula was used. Using the formula, the r-value for the pre-test was approximately 0.79 , and for the immediate and delayed post-tests were 0.81 and 0.78 .

\subsection{Procedure}

The course which was used for this study was a general proficiency course offering practice in the four skills. At first, the TOEFL PBT was administered to all the participants to ensure that their general knowledge of English is roughly at the same level. Then the background questionnaire was also given to them to choose the learners who were not familiar with the idea of collocations and had not experienced any kinds of collocation instruction before. In addition, as far as their knowledge of collocation was concerned, a pre-test in the second session was administered in order to ascertain that all the participants were initially homogeneous. Finally, the subjects were randomly classified into experimental and control groups and before the beginning of the experiment, they were all asked to take the GEFT to identify where they would fall on the spectrum of field-dependence/independence.

Since the possible individual and methodological differences between English language teachers can affect the students' performance, both experimental and control groups were taught by the same teacher within the same time span. The teacher exposed both groups to the same language input (audio, video and textual) and used the same course materials except for the materials that were used to expose the students in the experimental group to the target collocations.

More precisely, the teacher welcomed any chance to expose the subjects to the target collocations in the experimental group. Therefore, the rate of the target collocations was artificially increased in the materials used for the treatment. For example, the students were given some texts in which the target collocations were used and asked to answer some comprehension questions, give an oral or written summary or discuss the main ideas in class. Another activity, which was used for the input flood treatment, was unscrambling the sentences of some short paragraphs or the paragraphs of some reading texts. However, there was no mention of the target collocations and the kind of the exercises that they were asked to do required them to focus on understanding the content of the texts rather than learning collocations.

It is also important to note that in order to prevent the groups communicating with one another, their classes were held on different days and it was tried not to make them aware of each other.

One session before their final exam, the immediate post-test of collocation was administered to the participants to examine the short-term effect of the input flood treatment. Three weeks later, the participants were asked to take the delayed post-test of collocations in order to investigate the long-term effect of the treatment.

\subsection{Method of Data Analysis}

SPSS (Version 18) was used for analyzing the data.All data before analyzing were subjected to the normality test, and the results indicated that the data were normal. Therefore, independent and paired-samples t-test with the p-value of .05 were used to answer the questions of this study.

\section{Result and Discussion}

Firstly, in order to show that the groups were homogeneous and there was no significant difference between them at the beginning of the experiment, an independent sampled t-test was carried out.

Table 1. T-test for independent samples of pre-test

\begin{tabular}{lllllll}
\hline Groups & $\mathrm{N}$ & $\mathrm{M}$ & $\mathrm{SD}$ & $\mathrm{t}$ & $\mathrm{df}$ & $\mathrm{P}$ \\
\hline Control & 32 & 19.81 & 1.69 & .640 & 62 & .525 \\
Experimental & 32 & 19.53 & 1.82 & & & \\
\hline
\end{tabular}


As the above table indicates, the performance of the participants in the experimental group was not significantly different from the ones in the control group $(p=.525>.05)$. Therefore, their knowledge of collocation was roughly at the same level at the beginning of the treatment.

To answer the first research question dealing with the effect of input flood treatment on the subjects' knowledge of collocation, first, the pre-test scores of the participants in the experimental group were compared with their post-test scores.Then the performance of the learners in the experimental and control groups were compared with each other.

The results of the within experimental group comparison revealed that the learners' both immediate post-test $(\mathrm{M}=25.45, \mathrm{SD}=4.15)$ and delayed post-test $(\mathrm{M}=22.34, \mathrm{SD}=3.35)$ scores were significantly higher than their pre-test $(\mathrm{M}=19.53, \mathrm{SD}=1.82)$ scores $(\mathrm{p}=.000<.05)$.

Furthermore, as Table 2 reveals, the participants in the experimental group significantly outperformed the ones in the control group $(\mathrm{p}=.000<.05)$ in both immediate and delayed post-tests.

Table 2. T-test for independent samples of the immediate and delayed post-tests

\begin{tabular}{llllllll}
\hline Groups & & $\mathrm{N}$ & $\mathrm{M}$ & $\mathrm{SD}$ & $\mathrm{t}$ & $\mathrm{df}$ & $\mathrm{P}$ \\
\hline Immediate & Control & 32 & 19.96 & 1.66 & -6.93 & 62 & .000 \\
& Experimental & 32 & 25.45 & 4.15 & & & \\
\hline Delayed & Control & 32 & 19.84 & 1.65 & -3.78 & 62 & .000 \\
& Experimental & 32 & 22.34 & 3.35 & & & \\
\hline
\end{tabular}

Hence, in sum, the results proved the effectiveness of the input flood treatment on the subjects' collocation development in both short and long term.

To answer the second research question which deals with the role of the learners' cognitive style of field-dependence/independence in benefiting from the input flood treatment, first,the effect of input flood treatment on the field-dependent and field-independent learners' collocation development was separately examined. The analysis of the data indicated that the collocational knowledge of both field-dependent and field-independent learners in the input flood group was enhanced in short term $(p=.000<.05)$ but the long-term effect of the treatment remained only for the field-independent learners. In other words, the field-dependent learners' scores on the delayed post-test were not significantly higher than their pre-test scores $(p=.104>.05)$.

Furthermore, the results indicated that although the field-independent students' scores, in the input flood group, deteriorated significantly in three week time between the immediate post-test $(\mathrm{M}=28.79, \mathrm{SD}=2.07)$ and the delayed post-test $(M=24.73, S D=2.29)$, the significant difference between their pre-test $(M=19.55, S D=2.56)$ and delayed post-test scores $(\mathrm{M}=24.73, \mathrm{SD}=2.29)$ proved the effectiveness of the input-flood treatment on their long term memory as well as their short-term memory $(\mathrm{p}=.000<.05)$.

Then the possible differences between the field-dependent and field-independent learners in the input-flood group were explored to find out that which one benefited more from the treatment.

Table 3. T-test for independent samples of the field-dependent/independent learners' immediate and delayed post-tests in the input flood group

\begin{tabular}{llllllll}
\hline Groups & & $\mathrm{N}$ & $\mathrm{M}$ & $\mathrm{SD}$ & $\mathrm{t}$ & $\mathrm{df}$ & $\mathrm{P}$ \\
\hline Immediate & Field-independents & 17 & 28.79 & 2.07 & 9.65 & 30 & .000 \\
& Field-dependents & 15 & 21.66 & 2.09 & & & \\
\hline \multirow{2}{*}{ Delayed } & Field-independents & 17 & 24.73 & 2.29 & 6.64 & 30 & .000 \\
& Field-dependents & 15 & 19.63 & 2.01 & & & \\
\hline
\end{tabular}

As Table 3 reveals, the field-independent learners significantly $(p=.000<.05)$ outperformed the field-dependent ones in both immediate and delayed post-tests. Thus, the input-flood treatment was proved more beneficial for the field-independent learners.

Finally, the performance of the field-dependent and field-independent learners in the experimental group was compared with the ones in the control group. 
Table 4. T-test for independent samples of the field-independents' immediate and delayed post-tests

\begin{tabular}{llllllll}
\hline Groups & & $\mathrm{N}$ & $\mathrm{M}$ & $\mathrm{SD}$ & $\mathrm{t}$ & $\mathrm{df}$ & $\mathrm{P}$ \\
\hline Immediate & Control & 18 & 20.05 & 1.67 & -13.72 & 33 & .000 \\
& Experimental & 17 & 28.79 & 2.07 & & & \\
\hline Delayed & Control & 18 & 19.97 & 1.64 & -7.08 & 33 & .000 \\
& Experimental & 17 & 24.73 & 2.29 & & & \\
\hline
\end{tabular}

As shown in Table 4, in the case of field independent learners, the subjects in the input flood group achieved significantly higher scores than the ones in the control group in both immediate and delayed post-tests.

However, according to Table 5, the field-dependent learners in the experimental group meaningfully outperformed the ones in the control group only in the immediate post-test $(\mathrm{p}=.017<.05)$, and the difference between their means did not remain significant in the delayed post-test $(p=.949>.05)$.

Table 5. T-test for independent samples of the field-dependents' immediate and delayed post-tests

\begin{tabular}{llllllll}
\hline Groups & & $\mathrm{N}$ & $\mathrm{M}$ & $\mathrm{SD}$ & $\mathrm{t}$ & $\mathrm{df}$ & $\mathrm{P}$ \\
\hline Immediate & Control & 18 & 19.85 & 1.69 & .386 & 27 & .017 \\
& Experimental & 17 & 21.66 & 2.09 & & & \\
\hline Delayed & Control & 18 & 19.67 & 1.71 & -.578 & 27 & .949 \\
& Experimental & 17 & 19.63 & 2.01 & & & \\
\hline
\end{tabular}

The relationship between input-enhancement techniques, such as input-flood, and learner's noticing process is a controversial issue that has long been the subject of debate in second language acquisition (SLA). The two contradictory hypotheses that deal with this issue are Krashen's Input Hypothesis (1981) and Schmidt's Noticing Hypothesis (1990). The distinction between them is fully discussed by Ellis (1999) in his review of classroom-oriented research on input-based approaches to teaching grammar. He points out that Schmidt challenges Krashen's claim that mere exposure to comprehensible input can lead into learning the target features. In other words, Schmidt stresses the need for raising learners' awareness of what they attend to since he believes that detecting the linguistic features in the input cannot happen subconsciously. Hence, he does not reject Krashen's Input hypothesis, but believes that what Krashen claims can only be possible if input enhancement techniques are used to increase the chance of noticing the target features in input (Schmidt, 2001). Schmidt's claim regarding flooding the input, as one of the input enhancement techniques, was partially supported by the findings of the present study in favour of input-flood treatment. More precisely, the results revealed that input-flood treatment could only have beneficial effects on the noticing and learning process of some particular learners. These findings will be discussed in detail for each research question.

The findings for the first research question are in line with the findings of the previous studies which support the effectiveness of implicit methods of instruction (Ellis, 1997; Nation, 2001), and more specifically, for teaching lexical items (Beltran, 2004; Laufer, 2006; Nakata, 2007; Öztina, 2009; Zaferanieh \& Behrooznia, 2011). Hence, the results of this part are not consistent with the proponents of explicit instruction (Grabe \& Stoller, 1997; Schmitt \& McCarthy, 2002; Waring \& Takaki, 2003) who claim that conscious awareness is necessary. That is, since while no explicit methods of teaching were used to make the subjects of this study aware of the target items, the statistical analysis revealed that mere multiple exposure to the target collocations in different contexts could positively affect the participants' collocation development in both short and long term. By this way, the findings of this part lend support to the claim which is in favour of input flood and regards increasing the number of exposure to the target features as the effective factor in learning those features.

However, since the aim of the present study was to fill the gap which exists in the previous studies examining the impact of implicit instruction on learning linguistic features, the role of the learners' cognitive style of field-dependence/independence, which is believed to be crucial in benefiting from a teaching method (Nodoushan, 2006), was dealt with in the second research question. The findings of this part do not support the theoretical view of those researchers who assert that there is no significant relationship between the learners' cognitive style of field-dependence/independence and L2 learning since the difference between the performance of the field-dependent and field-independent learners in the input flood group was proved statistically meaningful. Furthermore, the results are also in sharp contrast to Dyer \& Osborne's (1999) study which claim that the effectiveness of various teaching approaches is not influenced by students' cognitive style of 
field-dependence/independence.

Moreover, the results concerning the superiority of field-independent learners to the field-dependent ones in both immediate and delayed post-tests are consistent with a number of studies (Boondao \& Rowley, 1991; Clark \& Roof, 1988; Dyer, 1995; Nodoushan, 2006; Tiajero et al., 2011) which claim that field-independent learners outperform the field-dependent ones in the learning tasks which require analysis and attention to details. In addition, similar to the studies which prove that field-dependent learners' memory is less efficient than field-independent ones' in processing, storing and consequently effective retention of information (Daniels, 1996; Mancy \& Reid, 2004; Willing, 1988), the results of this study reveal that the field-dependent learners could not retrieve the target collocations in the delayed post-test as well as the field-independent ones.

Furthermore, in spite of the fact that the mean of the field-dependent learners' immediate post-test in the input-flood group was meaningfully higher than their pre-test, and their performance on the immediate post-test was superior to the field-dependent ones' in the control group, their performance on the delayed post-test revealed that the treatment didn't have durable effect. Hence these results suggest that the field-dependent students can improve their knowledge of collocation to some extend through input flood treatment, but if there isn't any external support to help them focus on collocations upon a page and teach them how to store information in their working memory more efficiently in order not to have difficulty in accessing or retrieving the stored information, the learning will not have long-term effects.

In summary, the findings of this study proved the fact that field-independent learners are much better at restructuring skills and can attend to the tasks more selectively and mostly focus on details (Nilforooshan \& Afghari, 2007) more than the field-dependent ones. Hence, it can be claimed that in the case of the field-dependent learners, the results of this study lend support to the findings of some researchers, such as Laufer (2006), Seiba (2001) and Williams \& Evans (1998), who question the effectiveness of input flood treatment. According to these scholars, "noticing (if it is in fact noticed) the target feature does not necessarily indicate that it will be processed and become intake" (White, 2008; p. 26). Hence, field-dependent learners' attention is needed to be explicitly drawn to the target features they are expected to learn. However, in the case of field-independent learners, the results of the present study indicate that Schmidt's (1991) and Sharwood-smith's (1993) claim can be confirmed if the learners are exposed to the target collocations for a number of times.

On the whole, it can be argued that the contradictory results of the various studies on the effectiveness of input enhancement techniques, such as input-flood, are deeply rooted in the fact that most of these studies have overlooked the prominent role of the learners' individual differences.

\section{Conclusion and Implications}

There has been considerable debate about the role of learners' cognitive style of field-dependence/independence in language learning and benefiting from different teaching methods. Moreover, the effectiveness of input enhancement techniques on facilitating the noticing and learning of target forms in input has also been a matter of controversy, and research on this issue has yielded contradictory findings. This can be due to the fact that the crucial role of learners' differences in terms of their cognitive style and the strategies that they bring to a learning situation have been overlooked in this body of research. Thus, the present study examined the effect of input flood treatment on collocation knowledge development with regard to the learners' cognitive style of field-dependence/independence.

The findings of the present study suggest that input flood treatment cannot be beneficial for all types of learners. More precisely, the results of this study revealed that the field-independent learners could benefit from input flood treatment much more than the field-dependent ones in both immediate and delayed post-tests. On the other hand, although input flood treatment was proved to have long-term effect on improving the field-independent's knowledge of the target lexical and grammatical collocations, its effect was proved not to be durable for the field-dependent learners. These results stress the important role of attention, and are consistent with interactionist and cognitive views of laguage development that when a text is given to both field-dependent and field-independent learners, while the field-independent ones approach it analytically and focus on details, the field-dependent learners mostly pay attention to its global aspect and focus on comprehension of the content. Thus, the chance of noticing and then learning the target collocations in a text is much higher for field-independents due to their analytic nature. Moreover, the findings concerning the superiority of field-independent learners to the field-dependent ones in the delayed post-tests lend support to the claim by Daniels (1996) and Mancy \& Reid (2004) that field- independents categorize the information and store only the necessary and relevant one. As a result, the information can be retrieved more efficiently from their long-term memory. These findings might imply that while field independent learners can enhance their knowledge of 
collocations through input flood without any explicit instruction or feedback, the field dependent ones seem to need more explicit treatment types.

Hence, the results of this study support the findings of the studies which assert that the characteristics of the learners and the learning tasks can be considered the crucial factors in the success of an approach in a particular learning situation. This may provide convincing explanation for the mixed results of the previous studies on the effeciveness of input flood treatment on learning collocations. More precisely, these findings suggest that the learners' cognitive style of field-dependence/independence can be regarded as one of the most prominent factors in the success or failure of input-flood treatment in a particular learning environment. That is, the findings may imply that those studies which reported the input flood treatment as an efficient approach in enhancing the learners' knowledge of collocation might have participants with more field-independent characteristics. Therefore, these findings seem to have important implications for $\mathrm{L} 2$ teachers and learners.

As for teachers, if they become aware of their students' cognitive style of field-dependence/independence and learn more about the possible ways to help both groups improve their learning processes, they can adapt their teaching approaches to the different needs of the learners more effectively.

The findings of this study can also benefit language learners by encouraging them to learn more about their individual cognitive styles and thus developing their natural strengths and overcoming their weaknesses.

\section{References}

Abraham, R. G. (1985). Field independence/dependence and the teaching of grammar. TESOL Quarterly, 19, 689-702. http://dx.doi.org/10.2307/3586671

Alavi, S. M., \& Kaivanpanah, S. (2009). Examining the role of individual differences in lexical inferencing. Journal of Applied Sciences, 9(15), 2829-2834. http://dx.doi.org/10.3923/jas.2009.2829.2834

Allerton, D. J. (1984). Three (or four) levels of word co-occurrence restriction. Lingua, 63, 17-40. http://dx.doi.org/10.1016/0024-3841(84)90030-5

Alsakran, R. A. (2011). The productive and receptive knowledge of collocations by advanced Arabic-speaking ESL/EFL learners. M.A. dissertation, Colorado State University, United States - Colorado. Retrieved June 1, 2012, from Dissertations \& Theses: Full Text. (Publication No. AAT 1497925).

Altun, A., \& Cakan, M. (2006). Undergraduate Students' Academic Achievement, Field Dependent/Independent Cognitive Styles and Attitude toward Computers. Educational Technology \& Society, 9(1), 289-297.

Arp, L., Woodard, B. S., \& Mestre, L. (2008). Accommodating Diverse Learning Styles in an Online Environment. $\quad$ Retrieved April 20 2010, from http://www.rusq.org/2008/01/05/accommodating-diverse-learning-styles-in-an-online-environment/

Bahns, J. (1993). Lexical collocation: a contrastive view. ELT Journal, 47(1), 56-63. http://dx.doi.org/10.1093/elt/47.1.56

Bahns, J., \& Eldaw, M. (1993). Should we teach EFL students collocation? System, 21(1), 104-114. http://dx.doi.org/10.1016/0346-251X(93)90010-E

Beltran, R. C. (2004). The effects of focus on form in the teaching of Spanish - English false friends. RESLA, 17-18, 65-79.

Benson, M., Benson, E., \& Ilson, R. (1986). The BBI combinatory dictionary of English: A guide to word combinations. Amsterdam/Philadelphia: John Benjamins.

Benson, M., Benson, E., \& Ilson, R. (1997). The BBI dictionary of English word combinations (2 ${ }^{\text {nd }}$ edition). Amsterdam, The Netherlands: John Benjamins Publishing Company.

Boondao, S., \& Rowley, G. (1991). The effectof assignments for field-dependent/independent students in teaching mathematicsby distance education. AARE Conference. Queensland, Australia, November 26-30, 1991.

Brown, H. D. (2000). Principles of language learning and teaching (4th ed.). White Plains, NY: Addison, Wesley, Longman, Inc.

Case, R. (1974). Structures and strictures: Some functional limitations on the course of cognitive growth. Cognitive Psychology, 6, 544-574. http://dx.doi.org/10.1016/0010-0285(74)90025-5

Case, R., \& Globerson, T. (1974). Field-independence and central computing space. Child Development, 45, 722-778. http://dx.doi.org/10.2307/1127844 
Chen, S. Y., \& Macredie, R. D. (2002). Cognitive styles and hypermedia navigation: Development of a learning model. Journal of the American Society for Information Science and Technology, 53(1), 3-15. http://dx.doi.org/10.1002/asi.10023

Clark, H. T., \& Roof, K. D. (1988). Field dependence and strategy use. Perceptual and Motor Skills, 66, 303-307. http://dx.doi.org/10.2466/pms.1988.66.1.303

Coady, J., \& Huckin, T. (Eds.) (1997). Second-Language Vocabulary Acquisition: A Rationale for Pedagogy. Cambridge: Cambridge University Press.

Coward, R. T., \& Lange, G. (1979). Recall and recallorganization behaviours of field dependent and field-independent children. Psychological Reports, 44 191-197. http://dx.doi.org/10.2466/pr0.1979.44.1.191

Daniels, H. L. (1996). Interaction of cognitive style and learner control of presentation mode in a hypermedia $\begin{array}{lllll}\text { environment. } & \text { Retrieved } & \text { October } & 21, & \text { from }\end{array}$ http://scholar.lib.vt.edu/theses/available/etd-3132141279612241/

Danili, E., \& Reid, N. (2006). Cognitive factors that can potentially affect pupils' test performance. Retrieved February 25, 2009, from http://www.Rsc.org/images/danilireid\%20final_tcm18-52108.pdf

Dawson-Brew, E. (2010). The Relative Effect of Field Dependent and Field Independent Learning Styles on the Academic Performance of Undergraduate Students of the University of Cape Coast, Ghana. Retrieved November 25, 2010, from http://www.faqs.org/periodicals/201009/2087472301.html

Dukan, W. (2000). Vocabulary acquisition: Implicit learning and explicit teaching. REACT, 2, 15-22.

Durrant, P., \& Schmitt, N. (2010). Adult learners' retention of collocations from exposure. Second Language Research, 26(2), 163-188. http://dx.doi.org/10.1177/0267658309349431

Dyer, J. E. (1995). Effects of teaching approach on achievement, retention, and problem solving ability of Illinois agricultural education students with varying learning styles. Unpublished doctoral dissertation, University of Illinois at Urbana-Champaign.

Dyer, J. E., \& Osborne, E. W. (1996). Effects of teaching approach on achievement of agricultural education students with varying learning style. Journal of Agricultural Education, 3, 43-51. http://dx.doi.org/10.5032/jae.1996.03043

Ellis, R. (1994). The study of second language acquisition. Oxford: Oxford University Press.

Ellis, R. (1997). SLA research and language teaching. Oxford University Press, Oxford.

Ellis, R. (1999). Input-based approaches to teaching grammar: A review of classroom- oriented research. Annual Review of Applied Linguistics, 19, 64-80. http://dx.doi.org/10.1017/S0267190599190044

Fan, M. (2009). An exploratory study of collocational use by ESL students - A task based approach. System, 37, 110-123. http://dx.doi.org/10.1016/j.system.2008.06.004

Farfhal, M., \& Obiedat, H. (1995). Collocations: A neglected variable in EFL. IRAL, 33(4), 313-331.

Foel, N. A., \& Fritz, R. L. (1994). Association of cognitive style and satisfaction with distance learning. Journal of Industrial Teacher Education, 33, 46-59.

Fyle, C. O. (2009). The Effects of Field Dependent/Independent Style Awareness on Learning Strategies and Outcomes in an Instructional Hypermedia Module. A Dissertation submitted to the Department of Educational Psychology and Learning System in partial fulfilment of the requirements for the degree of Doctor of Philosophy. The Florida State University.

Gass, S. (1997). Input, Interaction, and the Second Language Learner. Erlbaum.

Goudarzi, Z., \& Moini, M. R. (2012). The Effect of Input Enhancement of Collocations in Reading on Collocation Learning and Retention of EFL Learners. International Education Studies, 5(3), $247-258$. http://dx.doi.org/10.5539/ies.v5n3p247

Griffiths, R., \& Sheen, R. (1992). Disembedded figures in the landscape: a reappraisal of L2 research on field dependence/independence. Applied Linguistics, 13, 133-148. http://dx.doi.org/10.1093/applin/13.2.133

Gul, F. A. (2009). Field Dependence Cognitive Style as a Moderating Factor in Subjects' Perceptions of Auditor $\begin{array}{lllll}\text { Independence. } & \text { Accounting } & \text { Finance, } & \text { 27(1). } & \text { 37-48. }\end{array}$ http://dx.doi.org/10.1111/j.1467-629X.1987.tb00234.x 
Hadley, A. (2003). Teaching Language in Context (Third Edition). Boston: Heinle \& Heinle Publishers.

Hall, J. K. (2000). Field Dependence-Independence and Computer-based Instruction in Geography. Dissertation Submitted to the Faculty of the Virginia Polytechnic Institute and State University in partial fulfillment of the requirements for the degree of Doctor of Philosophy in Teaching and Learning. Blacksburg, Virginia.

Hansen, J., \& Stanfield, C. (1981). The relationship of field dependent-independent cognitive style to foreign $\begin{array}{lllll}\text { language } \quad \text { achievement. language } & \text { 349-367. }\end{array}$ http://dx.doi.org/10.1111/j.1467-1770.1981.tb01389.x

Hill, J. (1999). Collocational competence. English Teaching Professional, 11.

Hill, J. (2000). Revising priorities: From grammatical failure to collocational success. In Michael Lewis (ed.), Teaching Collocation (pp. 47-70). Hove, England: Language teaching Publications.

Howarth, P. (1998). Phraseology and second language proficiency. Applied Linguistics, 19(1), 24-44. http://dx.doi.org/10.1093/applin/19.1.24

Hsu, J. (2007). Lexical collocations and their relation to the online writing of Taiwanese college Englishmajors. Electronic Journal of Foreign Language Teaching, 4(2), 192-209.

Johns, T. F. (1991). From Printout to Handout: Grammar and Vocabulary Teaching in the Context of Data-driven Learning. In Johns, T. F., \& King, P. (eds.). (1991). pp. 27-37.

Koosha, M., \& Jafarpour, A. (2006). Data-driven Learning and Teaching collocation of prepositions: The Case of Iranian EFL Adult Learners. Asian EFL Journal, 8(8), 192-209.

Krashen, S. D. (1981). Second language acquisition and second language learning. Oxford: Pergamon Press.

Krashen, S. D. (1989). We acquire vocabulary and spelling by reading: Additional evidence for the Input $\begin{array}{lllll}\text { Hypothesis. The Modern } & \text { 4anguage }\end{array}$ http://dx.doi.org/10.1111/j.1540-4781.1989.tb05325.x

Laufer, B. (2006). Comparing focus on form and focus on forms in second language vocabulary learning. The Canadian Modern Language Review, 63(1), 149-166. http://dx.doi.org/10.1353/cml.2006.0047

Le, T. H. (2010). Learning lexical collocations with concordancing and scaffolding. Retrieved December 20, 2011,

from http://scripties.let.eldoc.ub.rug.nl/FILES/root/Master/DoorstroomMasters/ToegepasteTaalwetens/2010/Le/ MA_1938851_T_H_Le.pdf

Lennon, P. (1996). Getting 'easy' verbs wrong at the advanced level. IRAL, 34(1), 23-36.

Lewis, M. (2000). Language in the lexical approach. In M. Lewis (ed), Teaching collocation: Further developments in the lexical approach (pp.155-184). London: Language Teaching Publications.

Lewis, M. (2001). There is nothing as practical as a good theory. In Michael Lewis (ed.), Teaching collocation: Further developments in the lexical approach (pp. 10-27). London: Language Teaching Publications.

Lin, Y. P. (2002). The effects of collocation instruction on English vocabulary development of junior high school students in Taiwan. Unpublished master thesis, National Kaohsiung Normal University, Kaohsiung, Taiwan.

Mancy, R., \& Reid, N. (2004). Aspects of cognitive style and programming. In E. Dunican, \& T. Green (Eds.), Proceedings of the Sixteenth Annual Workshop of the Psychology of Programming Interest Group (PPIG '04; pp. 1-9). Carlow, Ireland: Institute of Technology.

Martyńska, M. (2004). Do English language learners know collocations? Investigationes Linguisticae, 6, 1-12.

McEwan, R. C., \& Reynolds, S. (2007). Verbalisers and Visualisers: Cognitive Styles That Are Less Than Equal. Retrieved May 15, 2010, from http://www.fanshawec.ca/sites/default/files/file_attachments/mcewan2007.pdf

Motallebzadeh, Kh., Beh-Afarin, R., \& Rad, D. S. (2011). The Effect of Short Message Service on the Retention of Collocations among Iranian Lower Intermediate EFL Learners. Theory and Practice in Language Studies, 1(11), 1514-1520. http://dx.doi.org/10.4304/tpls.1.11.1514-1520

Nagy, W. E., \& Herman, P. A. (1987). Breadth and depth of vocabulary knowledge: Implications for acquisition and instruction. In M. G. McKeown, \& M. E. Curtis (Eds.), The Nature of Vocabulary Acquisition (pp. 19-35). Hillsdale, N.J.: Lawrence Erlbaum.

Nakata, T. (2007). English collocation learning through meaning-focused and form- focused tasks. Proceedings 
of the 11th Conference of Pan-Pacific Association of Applied Linguistics, 154-168. Retrieved October 15, 2010, from http://www.paaljapan.org/resources/proceedings/PAAL11/pdfs/13.pdf

Nesselhaulf, N. (2003). The use of collocations by advanced learners of English and some implications for teaching. Applied Linguistics, 24(2), 223-242. http://dx.doi.org/10.1093/applin/24.2.223

Nilforooshan, N., \& Afghari, A. (2007). The Effect of Field Dependence-Independence as a Source of Variation in EFL Learners' Writing Performance. Iranian Journal of Language Studies (IJLS), 1(2), 103-118.

Nodoushan, M. A. (2006). Does cognitive style affect communicative language tests. Language, Society and Culture, 19.

Öztina, S. (2009). Effects of Input Flood and Negative Evidence on Learning of Make/Do Collocations: A Study with Seventh Grade Turkish EFL Students. A dissertation submitted to the graduate school and research in the fulfillment of the requirements for the degree master of arts, Anadolu University Institute of Educational Sciences.

Pei, C. (2008). Review of empirical studies on collocation in the field of SLA. Retrieved May 2, 2010, from http://www.celea.org.cn/teic/82/82-72.pdf

Rassaei, \& Karbor. (2012). The effects of three types of attention drawing techniques on the acquisition of English collocations. International Journal of Research Studies in Language Learning, 1, 1-14.

Roberts, C. R. (1983). Depth of involvement, imagery, and daydreaming: A study of altered states of consciousness and orgasmic success in women. Dissertation Abstracts International.

Scardamalia, M. (1977). Information processing capacity and the problem of horizontal decalage: A demonstration using combinatorial reasoning tasks. Child Development, 48(1), 28-37. http://dx.doi.org/10.2307/1128877

Schmidt, R. (1990). The role of consciousness in second language learning. Applied Linguistics, 11, $129-158$. http://dx.doi.org/10.1093/applin/11.2.129

Schmidt, R. (2001). Attention. In P. Robinson (Ed.), Cognition and second language instruction (pp. 3-32). Cambridge University Press.

Seiba, Z. (2001). Classroom Instruction and Second Language Acquisition: The effect of explicit form-focused instruction on L2 learners' linguistic competence. A doctoral dissertation presented to the University of Mississippi, Oxford, Mississippi.

Sharwood-Smith, M. (1993). Input enhancement in instructed SLA: Theoretical bases. Studies in Second Language Acquisition, 15(2), 165-179. http://dx.doi.org/10.1017/S0272263100011943

Shehata, A. K. (2008). L1 Influence on the Reception and Production of Collocations by Advanced ESL/EFL Arabic Learners of English. Retrieved January 12, 2010, from http://etd.ohiolink.edu/send-pdf.cgi/Shehata\%20Asmaa\%20K.pdf?ohiou1218237449

Shokouhi, H., \& Mirsalari, Gh. (2010). Collocational Knowledge versus General Linguistic Knowledge among Iranian EFL Learners. The Electronic Journal for English as a Second Language. Retrieved October 2, 2011, from http://www.tesl-ej.org/wordpress/issues/volume13/ej52/ej52a7/

Sims, R. R., \& Sims, S. J. (2006). Learning styles and learning: A key to meeting the accountability demands in education. New York: Nova Science Publishers.

Sinclair, J. M. (1991). Corpus, Concordance, Collocation. Oxford: Oxford University Press.

Tianjero, C., Castelo, A., Guisande, A., \& Páramo, F. (2011). Adaptive Teaching and Field Dependence-Independence: Instructional Implications. Revista Latinoamericana de Psicología Volumen, 43(3), 497-510.

Trahey, M., \& L. White. (1993). Positive evidence and preemption in the L2 classroom. Studies in Second Language Acquisition, 15, 181-204. http://dx.doi.org/10.1017/S0272263100011955

Wei, Y. (1999). Teaching collocations for productive vocabulary development. Paper presented at the Annual Meeting of the Teachers of English to Speakers of Other Languages. New York.

White, J. P. (2008). The effect of input-based instruction type on the acquisition of Spanish accusative CLITICS. A dissertation submitted to thedepartment of Modern Languages and Linguistics in partial fulfillment of the requirements for the degree of Doctor of Philosophy. Florida State University. 
Williams, J., \& Evans, J. (1998). What kind of focus and on which forms? In Doughty and Williams (Eds.). pp. $139-155$.

Willing, K. (1988). Learning styles in adult migrant education. Adelaide, South Australia: National Curriculum Research Council.

Witkin, H. A., \& Goodenough, D. R. (1981). Cognitive Styles: Essence and Origins. NY: International Universities Press.

Witkin, H. A., Moore, C. A., Goodenough, D. R., \& Cox, P. W. (1977). Field-dependent and field-independent cognitive styles and their educational implications. Review of Educational Research, 47(1), 1-64. http://dx.doi.org/10.3102/00346543047001001

Witkin, H. A., Oltman, P. K., Raskin, E., \& Karp, S. A. (1971). A manual for the Embedded Figures Test. Consulting Psychologist Press, Palo Alto, CA.

Wong, W. (2005). Input enhancement: From theory and research to the classroom. Boston: McGraw-Hill.

Wu, S., Franken, M., \& Witten, I. H. (2010). Supporting collocation learning with a digital library. Computer Assisted Language Learning, 23(1), 87-110. http://dx.doi.org/10.1080/09588220903532971

Yousefi, M. (2011). Cognitive style and EFL learners' listening comprehension ability. Retrieved October, 2011, from http://jurnal.upi.edu/file/06-Mandana_COGNITIVE_STYLE.pdf

Zaferanieh, E., \& Behrooznia, S. (2011). On the Impacts of Four Collocation Instructional Methods: Web-Based Concordancing vs. Traditional Method, Explicit vs. Implicit Instruction. Studies in Literature and Language, 3(3), 120-126.

Zahedi, H., \& Mirzadeh, Kh. M (2010). Collocational Cloze: The Effect of Deletion Procedure and Gender. The Iranian EFL Journal, 6(1).

Zughoul, M. R (1991). Lexical choice: Towards writing problematic word lists. lRAL, 24(1), 45-60. 